\title{
Detection and characterization of Chrysanthemum virus B (CVB) isolates in Poland
}

\author{
Wykrywanie i charakterystyka izolatów wirusa B chryzantemy \\ (Chrysanthemum virus $B, C V B$ ) w Polsce
}

Aleksandra Zarzyńska-Nowak, Beata Hasiów-Jaroszewska, Natasza Borodynko, Henryk Pospieszny

\section{Summary}

In 2013 and 2014 in the Plant Disease Clinic of Institute of Plant Protection - National Research Institute in Poznań, chrysanthemum plants showing symptoms of stunted growth, mosaic and malformation of leaves and abnormal pigmentation of flowers were tested. All plants were analyzed using biological, electron microscopy and molecular biology methods. The plants were examined for the presence of the following pathogens: Chrysanthemum virus B (CVB), Tomato aspermy virus (TAV), Chrysanthemum stunt viroid (CSVd) and Chrysanthemum chlorotic mottle viroid (CChMVd). The presence of CVB was confirmed in the samples collected from 15 plants. The isolates were genetically identical and shared high level of similarity with isolates from India and Japan.

Key words: Chrysanthemum virus B; electron microscopy; RT-PCR; phylogenetic analysis

\section{Streszczenie}

W latach 2013-2014 w Klinice Chorób Roślin Instytutu Ochrony Roślin - Państwowego Instytutu Badawczego w Poznaniu testowano rośliny chryzantemy wykazujące objawy: zahamowania wzrostu, mozaiki i deformacji blaszek liściowych oraz nieprawidłowej pigmentacji kwiatów. Przeprowadzono testy biologiczne, obserwacje mikroskopowe oraz badania z zastosowaniem technik biologii molekularnej. Rośliny testowano na obecność patogenów takich, jak: wirus B chryzantemy (Chrysanthemum virus $B$, CVB), wirus aspermii pomidora (Tomato aspermy virus, TAV), wiroid karłowatości chryzantemy (Chrysanthemum stunt viroid, CSVd) oraz wiroid chlorotycznej plamistości chryzantemy (Chrysanthemum chlorotic mottle viroid, CChMVd). W 15 próbach wykryto jedynie wirusa B chryzantemy. Sekwencje nukleotydów genu białka płaszcza badanych izolatów CVB były identyczne. Analiza filogenetyczna wykazała podobieństwo genetyczne polskich izolatów CVB do izolatów z Indii i Japonii.

Słowa kluczowe: Chrysanthemum virus B; mikroskopia elektronowa; RT-PCR; analiza filogenetyczna

Instytut Ochrony Roślin - Państwowy Instytut Badawczy

Zakład Wirusologii i Bakteriologii

Władysława Węgorka 20, 60-318 Poznań

A.Zarzynska@iorpib.poznan.pl 


\section{Wstęp / Introduction}

Należący do rodzaju Carlavirus (rodzina Betaflexiviridae), wirus B chryzantemy (Chrysanthemum virus B, CVB) jest jednym $\mathrm{z}$ najgroźniejszych patogenów tej rośliny (Singh i wsp. 2007; Verma i wsp. 2007). Ze względu na jego powszechne występowanie może stanowić poważne zagrożenie dla uprawy chryzantemy. Infekcja wirusem może powodować zahamowanie wzrostu roślin, deformację i przebarwienie kwiatów (Ohkawa i wsp. 2007) lub może przebiegać bezobjawowo. CVB jest przenoszony w sposób nietrwały przez wiele gatunków mszyc, m.in.: Myzus persicae, Macrosiphum euphorbiae, Aulacorthum solani, Coloradoa rufomaculata i Macrosiphoniella sanborni. Patogen może być również przenoszony mechanicznie (Kryczyński 2009).

Cząstki wirusa mają kształt nitkowaty, długość około $680 \mathrm{~nm}$ i średnicę około $12 \mathrm{~nm}$ (Verma i wsp. 2003). Genom CVB zbudowany jest $\mathrm{z}$ pojedynczej nici RNA (ribonucleic acid) (około $8800 \mathrm{nt}$ ) o pozytywnej orientacji i podobnie, jak u innych przedstawicieli rodzaju Carlavirus, zawiera sześć ramek odczytu (Open Reading Frames ORFs). Pierwsza z nich, ORF1, koduje białko biorące udział $w$ replikacji wirusa, kolejne ORF2, 3 i 4 kodują kompleks białkowy odpowiedzialny za przemieszczanie się wirusa z komórki do komórki (Triple Gene Block, TGB), ORF5 koduje białko płaszcza, natomiast ostatnia ramka odczytu koduje białko mające zdolność do wiązania się z kwasami nukleinowymi. Jego funkcja nie jest do końca poznana, lecz przypuszczalnie bierze ono udział w procesie przenoszenia wirusa przez mszyce, bądź jest zaangażowane w transkrypcję genów gospodarza, wyciszanie genów lub w proces replikacji wirusowego RNA (Adams i wsp. 2012).

W latach 2013-2014 w Klinice Chorób Roślin Instytutu Ochrony Roślin - Państwowego Instytutu Badawczego w Poznaniu testowano 20 roślin chryzantemy pochodzących z uprawy szklarniowej, wykazujących objawy zahamowania wzrostu, mozaiki i deformacji blaszek liściowych oraz nierównomiernego wybarwienia kwiatów. W celu zidentyfikowania przyczyny powstałych zmian rośliny przetestowano technikami biologicznymi, mikroskopowymi oraz molekularnymi.

\section{Materiały i metody / Materials and methods}

\section{Mikroskopia elektronowa}

Pierwszym etapem badań było wykonanie dla każdej z 20 roślin preparatów mikroskopowych. Na pokryte formwarem miedziane siateczki naniesiono sok roślinny uzyskany z roztartych w wodzie porażonych liści. Po $1 \mathrm{mi}-$ nutowej inkubacji preparaty wybarwiano kwasem fosforowolframowym o pH 7,2 i przeglądano w transmisyjnym mikroskopie elektronowym Hitachi HT7700, przy napięciu przyspieszającym wynoszącym $80 \mathrm{kV}$.

\section{Test biologiczny}

W celu ustalenia zakresu roślin gospodarzy oraz objawów na nich wywoływanych, liście chryzantemy z widocznymi zmianami roztarto $\mathrm{w}$ buforze fosforanowym o pH 7,0. Otrzymanym sokiem inokulowano następujące rośliny wskaźnikowe: komosę ryżową (Chenopodium quinoa), petunię ogrodową (Petunia hybrida), szpinak nowozelandzki (Tetragonia expansa), ogórka siewnego (Cucumis sativus) oraz tytonie (Nicotiana glutinosa, $N$. tabacum odmiana Xanthi, Samsun i White Burley). Rośliny utrzymywano w stałej temperaturze $23^{\circ} \mathrm{C}$ w warunkach 16-godzinnego doświetlania.

\section{RT-PCR (reverse transcription-polymerase chain reaction)}

Całkowity RNA wyizolowano ze 100 mg liści porażonych roślin stosując zestaw RNeasy ${ }^{\circledR}$ Plant Mini Kit (Qiagen), zgodnie $\mathrm{z}$ zaleceniami producenta. Reakcję odwrotnej transkrypcji i łańcuchowej polimerazy przeprowadzono za pomocą zestawu Transcriptor One-Step RTPCR (Roche), zgodnie z zaleceniami producenta. Dla każdej rośliny przeprowadzono osobną reakcję z użyciem starterów literaturowych: CVB F/R, TAV F/R, CSVd F/R i CChMVd F/R, zaprojektowanych na podstawie sekwencji CVB, wirusa aspermii pomidora (Tomato aspermy virus, TAV), wiroida karłowatości chryzantemy (Chrysanthemum stunt viroid, CSVd) oraz wiroida chlorotycznej plamistości chryzantemy (Chrysanthemum chlorotic mottle viroid, CChMVd) (Song i wsp. 2012). Reakcję odwrotnej transkrypcji prowadzono $\mathrm{w}$ temperaturze $50^{\circ} \mathrm{C}$ przez $30 \mathrm{~min}$, a następnie, po wstępnej denaturacji $\mathrm{w} 94^{\circ} \mathrm{C}$ przez $7 \mathrm{~min}$, przeprowadzono reakcję PCR w następujących cyklach termicznych: $94^{\circ} \mathrm{C}$ przez $10 \mathrm{~s} ; 52^{\circ} \mathrm{C}$ (dla $\mathrm{CSVd}$ ) lub $55^{\circ} \mathrm{C}$ (dla CVB, TAV i CChMVd) przez $30 \mathrm{~s} ; 68^{\circ} \mathrm{C}$ przez $1 \mathrm{~min}$ oraz końcowe wydłużenie w $68^{\circ} \mathrm{C}$ przez 7 minut.

Otrzymane produkty RT-PCR rozdzielano elektroforetycznie na $1 \%$ żelu agarozowym z dodatkiem barwnika Midori Green DNA Stain (Nippon Genetics Europe $\mathrm{GmbH}$ ). Produkty oczyszczano z żelu za pomocą NucleoSpin ${ }^{\circledR}$ Gel and PCR Clean-up (Machery-Nagel), zgodnie $\mathrm{z}$ zaleceniami producenta i ligowano do wektora pGEM TEasy (Promega). Następnie przeprowadzano transformację metodą szoku termicznego do komórek kompetentnych Escherichia coli TOP10 (Invitrogen). Plazmidowe DNA (deoxyrybonucleic acid) izolowano z użyciem zestawu NucleoSpin @ Plasmid (NoLid) (Machery-Nagel). Obecność insertów weryfikowano poprzez trawienie enzymem restrykcyjnym EcoRI (Thermo Scientific). DNA sekwencjonowano $\mathrm{z}$ użyciem uniwersalnych starterów M13F/R w firmie Genomed S.A.

\section{Analiza filogenetyczna}

Uzyskane sekwencje nukleotydów analizowano przy użyciu programu BioEdit (Hall 1999), a następnie zamieszczono je w Banku Genów. Drzewo filogenetyczne skonstruowano metodą największej wiarygodności w programie MEGA 5.2 (Tamura i wsp. 2011) z wykorzystaniem otrzymanych sekwencji oraz sekwencji zdeponowanych w Banku Genów. 


\section{Wyniki i dyskusja / Results and discussion}

\section{Mikroskopia elektronowa}

Obserwacja w transmisyjnym mikroskopie elektronowym wykazała obecność w 15 preparatach nitkowatych cząstek o długości około $680 \mathrm{~nm}$ i średnicy około $12 \mathrm{~nm}$ typowych dla wirusów z rodzaju Carlavius (rys. 1).

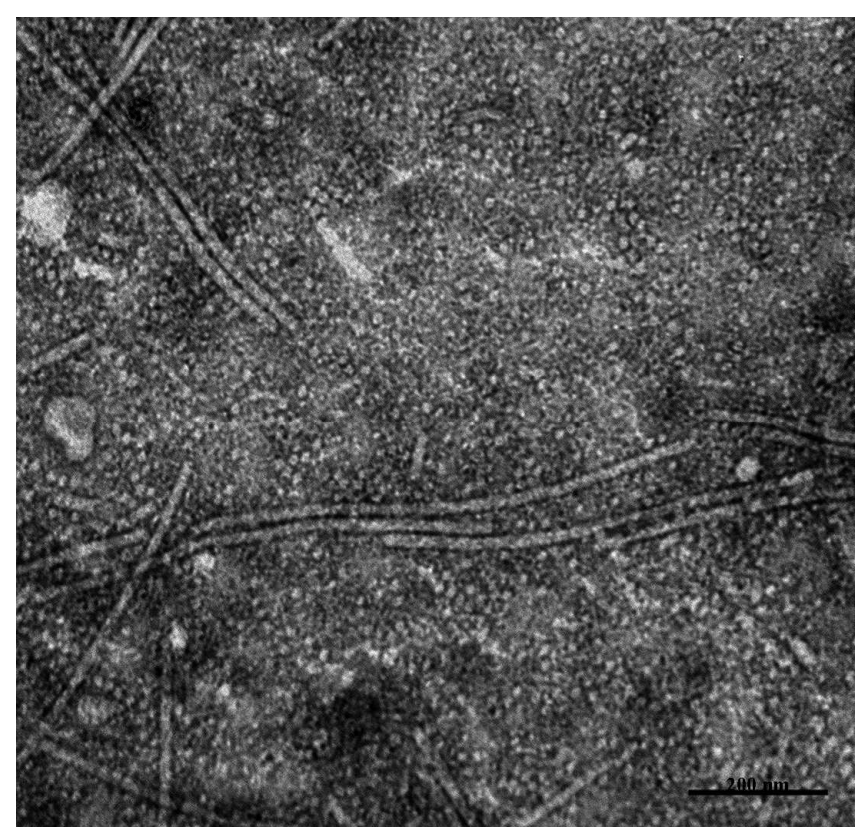

Rys. 1. Nitkowate cząstki wirusa widoczne w transmisyjnym mikroskopie elektronowym

Fig. 1. Filamentous virus particles observed in transmission electron microscopy

\section{Test biologiczny}

$\mathrm{Na}$ roślinach petunii, szpinaku oraz tytoniu, po trzech tygodniach od inokulacji obserwowano objawy chorobowe. Na liściach $P$. hybrida oraz T. expansa występowały lokalne, żółte, chlorotyczne plamy. W przypadku dwóch odmian tytoniu również odnotowano obecność lokalnych plam, przy czym na $N$. glutinosa były one chlorotyczne, zaś na $N$. tabacum odmiany Xanthi - nekrotyczne. Na pozostałych gatunkach roślin testowych nie obserwowano żadnych zmian. Dla każdej $\mathrm{z}$ roślin przeprowadzono obserwacje mikroskopowe, które potwierdziły obecność nitkowatych cząstek wirusa w próbach wykonanych $\mathrm{z}$ roślin wykazujących objawy chorobowe oraz ich brak w preparatach z roślin bez objawów porażenia.

\section{RT-PCR}

W 15 badanych próbach otrzymano produkt o oczekiwanej wielkości 620 par zasad, potwierdzający porażenie roślin przez CVB (rys. 2). Próby te pochodziły z roślin, w których soku obserwowano w transmisyjnym mikroskopie elektronowym obecność cząstek wirusa. W badanych próbach liści z 20 roślin chryzantemy nie wykryto TAV oraz wiroidów.

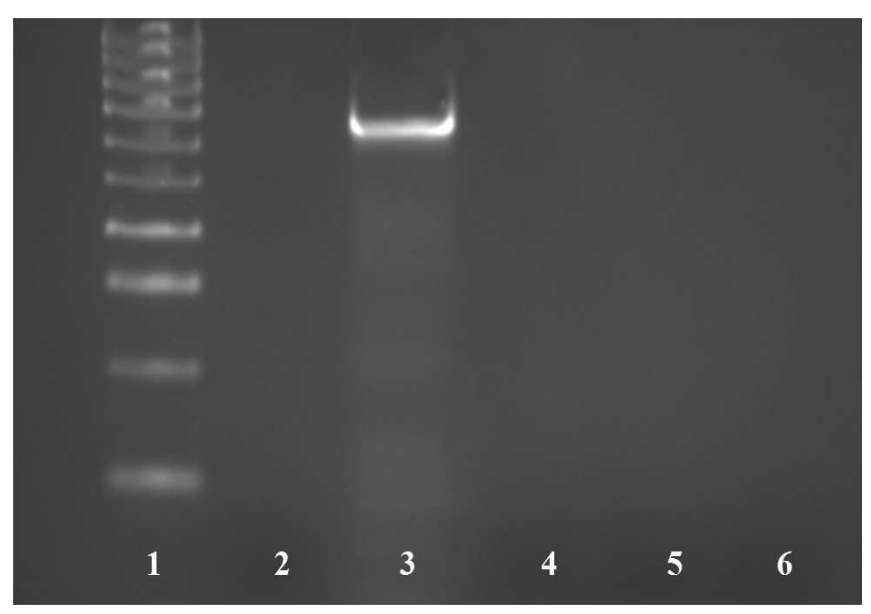

Rys. 2. Rozdział elektroforetyczny dla jednej próby chryzantemy badanej testem RT-PCR na obecność czterech patogenów. 1 - marker HyperLadder IV(Bioline), 2 kontrola negatywna, 3 - CVB, 4 - TAV, 5 - SCVd, $6-\mathrm{CChMVd}$

Fig. 2. Electrophoretic separation of RT-PCR product obtained for one plant sample examined for the presence of four pathogens. 1 - DNA ladder HyperLadder IV(Bioline), 2 - negative control, 3 - CVB, 4 - TAV, 5 - SCVd, 6 - CChMVd

\section{Analiza filogenetyczna}

Uzyskane sekwencje z 15 prób były identyczne. Jedna z sekwencji została zdeponowana w Banku Genów pod numerem akcesyjnym: KJ489421. Analiza drzewa filogenetycznego skonstruowanego na podstawie sekwencji nukleotydów polskiego izolatu CVB oraz 32 sekwencji innych izolatów pozyskanych z Banku Genów wykazała, iż polski izolat grupuje się $\mathrm{z}$ izolatami $\mathrm{z}$ Indii (nr akcesyjne: AJ585514.1, AJ812569.1 i AJ871367.1) oraz z izolatem z Japonii (nr akcesyjny: AB245142.1) (rys. 3).

Wirus B chryzantemy jest szeroko rozpowszechniony na świecie i wykazuje wysoki stopień zróżnicowania genetycznego. Analiza sekwencji genu kodującego białko płaszcza 29 izolatów CVB zebranych w Indiach wykazała 74-98\% podobieństwa (Singh i wsp. 2007). W Polsce wirus był wykrywany głównie za pomocą testów serologicznych, stąd niewiele wiadomo na temat zróżnicowania jego populacji. Dostępne dane z 2000 roku szacują procent porażenia chryzantem przez CVB od 8 do 41 (Balukiewicz i Kryczyński 2001). Stwierdzona w badaniach homologia sekwencji izolatów przetestowanych w 2013 i 2014 roku może wskazywać na wspólne źródło zakażenia. Interesujący jest fakt, że polskie izolaty wykazały wysoki stopień pokrewieństwa genetycznego $\mathrm{z}$ izolatami $\mathrm{z}$ Indii i Japonii. Ze względu na szkodliwość wirusa oraz potencjalne straty, jakie może on wywoływać w uprawie, zdrowotność materiału roślinnego powinna podlegać kontroli. Zaplanowano opracowanie techniki izotermalnej amplifikacji DNA umożliwiającej wykrywanie szerokiego spektrum izolatów w warunkach szklarniowych bez potrzeby stosowania drogiej aparatury. 


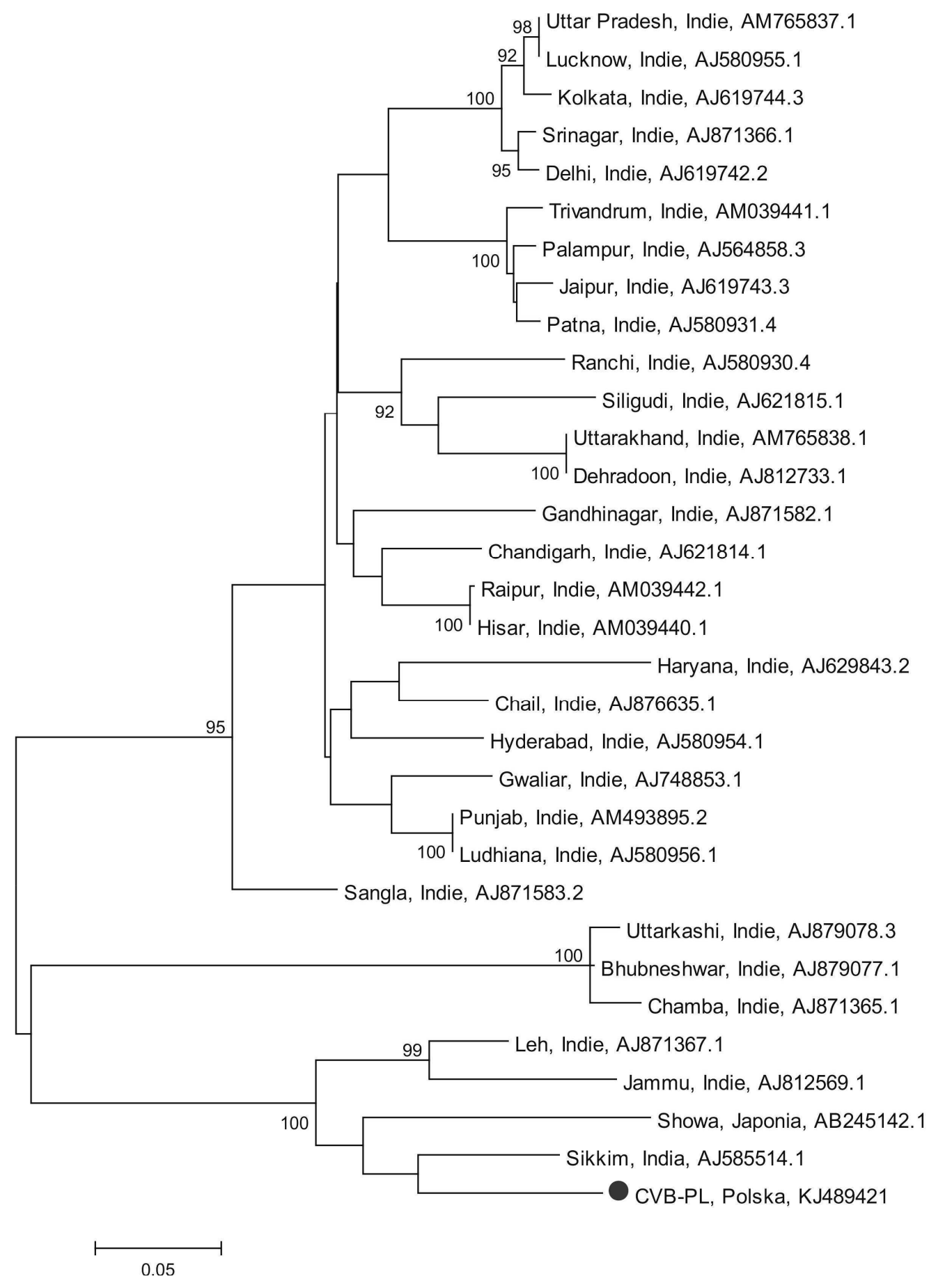

Rys. 3. Drzewo filogenetyczne uzyskane na podstawie sekwencji nukleotydów polskiego izolatu CVB oraz izolatów zdeponowanych w Banku Genów. Polski izolat oznaczono kropką

Fig. 3. Phylogenetic tree constructed based on the obtained nucleotide sequences of CVB Polish isolate and other CVB isolates deposited in the GenBank database. Polish isolate is marked by dot

\section{Wnioski / Conclusions}

1. W soku roślinnym uzyskanym $\mathrm{z}$ porażonych roślin chryzantemy, stwierdzono obecność nitkowatych cząstek wirusa o długości $680 \mathrm{~nm}$ i średnicy około $12 \mathrm{~nm}$.
2. Spośród 20 roślin chryzantemy testowanych w Klinice Chorób Roślin, 15 porażonych było wirusem B chryzantemy.

3. Analiza filogenetyczna wykazała podobieństwo polskich izolatów CVB do izolatów z Indii i Japonii. 


\section{Literatura / References}

Adams M.J., Candresse T., Hammond J., Kreuze J.F., Martelli G.P., Namba S., Pearson M.N., Ryu K.H., Saldarelli P., Yoshikawa N. 2012. Family Betaflexiviride, Genus Carlavirus. p. 1143-1147. In: „Virus Taxonomy, Classification and Nomenclature of Viruses” (A.M.Q. King, M.J. Adams, E.B. Carstens, E.J. Lefkowitz, eds). Academic Press, London, 1327 pp.

Balukiewicz A., Kryczyński S. 2001. Viruses in chrysanthemum mother stock plants in Poland. Phytopathol. Pol. 22: $107-115$.

Hall T.A. 1999. BioEdit: a user-friendly biological sequence alignment editor and analysis program for Windows 95/98/NT. Nucl. Acids. Symp. Ser. 41: 95-98.

Kryczyński S. 2009. Najważniejsze wirusy i wiroidy chryzantem ze szczególnym uwzględnieniem tego problemu w Polsce. Post. Nauk Rol. 2: 71-88.

Ohkawa A., Yamada M., Sayama H., Sugiyama N., Okuda S., Natsuaki T. 2007. Complete nucleotide sequence of Japanese isolate of Chrysanthemum virus B (genus Carlavirus). Arch. Virol. 152: 2253-2258.

Singh L., Hallan V., Jabeen N., Singh A.K., Ram R., Martin D.P., Zaidi A.A. 2007. Coat protein gene diversity among Chrysanthemum virus $B$ isolates from India. Arch. Virol. 152: 405-413.

Song A., You Y., Chen F., Li P., Jiang J., Chen S. 2012. A multiplex RT-PCR for rapid and simultaneous detection of viruses and viroids in chrysanthemum. Let. Appl. Microbiol. 56: 8-13.

Tamura K., Peterson D., Peterson N., Stecher G., Nei M., Kumar S. 2011. MEGA5: Molecular Evolutionary Genetics Analysis using Maximum Likelihood, Evolutionary Distance, and Maximum Parsimony Methods. Mol. Biol. Evol. 28: 2731-2739.

Verma N., Mehra A., Singh L., Hallan V., Singh A.K., Jabeen N., Singh M.K., Ram R., Zaidi A.A. 2007. Screening for viruses infecting chrysanthemum cultivars in India. Sci. Hortic. 111: 260-265.

Verma N., Sharma A., Ram R., Hallan V., Zaidi A.A. 2003. Detection, identification and incidence of Chrysanthemum B carlavirus in chrysanthemum in India. Crop Prot. 22: 425-429. 